\title{
Impact of Migration on Culture, Behavior, and Health: A Study of the Migrant Population in Delhi.
}

\author{
Anu Bhawana \\ Department of Anthropology, University of Delhi, Delhi-110007 India
}

\begin{abstract}
Migration is a spatial change of place which with due course of time affects the culture, behavior, and health of the migrant population. This paper will try to explore the behavioral and cultural parameters that are essential to understanding the issues of economic status and its correlation to the health dynamics of a particular population. It also talks about the methodological aspect of carrying out a research on the migrant population, keeping in account the issues and efforts to help those population in distress.
\end{abstract}

Keywords: Behavior, Class, Culture, Health, Migration.

\section{Introduction}

Migration has long been the subject of considerable anthropological as well as sociological attention. The social scientists have long recognized the importance of migration as a factor of social change. They have expended large amounts of effort in analyzing this phenomenon. When it comes to explain migration especially 'Human Migration', it can be broadly described as a major demographic process that has been an integral and salient feature of human history since time immemorial. It has been an important means by which human civilization has spread out, enriching cultures, disseminating ideas and generating social, political and economic changes at the place of origin and of destination. As an area of study, migration has been continuously drawing the attention of policy planners and academicians in looking into the various impact of public mobility from place to place. This has been particularly so in the case of developing societies which are in the process of social transformation because it includes people who move for different reasons across different spaces. This research study focuses on the socio-cultural dynamics of a migrant population living in the Seelampur (located in the north east area of Delhi), and its impact on their behavior and health.

\section{Cause Of Migration}

The causes of migration are related to the specific contexts in which they take place. First, the compositions of migration streams are characterized by structural forces such as the global economy. Second, socio-cultural differentials (gender, class, caste, etc.) have important implications for individual mobility. The second causative agents are more implacable in Indian context. While some modern migration is a by-product of turbulence in the society (war, communal riots, insurgency, caste conflicts, etc.), political conflicts, and natural disasters, contemporary migration is predominantly economically motivated. In particular, there are wide disparities in the incomes that can be earned for similar work in different places within as well as outside the country. There are also at any given time some jobs in some high-wage places for which there is a shortage of appropriately skilled or qualified persons. Migration occurs at a variety of scales: intercontinental, intracontinental, and interregional. One of the most significant migration patterns has been rural to urban migration - the movement of people from the countryside to cities in search of opportunities.

\subsection{Seasonal human migration:}

\section{Types Of Migration}

This is mainly related to agriculture and tourism. It is a temporary kind of migration or more specifically a 'cyclic' migration where migrants come over a particular place in a work season and repeat this cycle after a period of time.

\subsection{Rural to Urban:}

It is more common in developing countries as industrialization takes effect (urbanization).

\subsection{Urban to Rural:}

It is more common in developed countries due to a higher cost of urban living (suburbanization). 


\section{Seelampur: An Overview}

Approximately $15 \mathrm{~km}$ from the centre of Delhi, a small settlement is located called Seelampur, reputedly the largest electronics dismantling-recycling-selling market in the country. Residents work every day to extract gold, copper and aluminum from different kind of circuit boards and electric wires of various diameters. Some extract metals independently, some work with big traders - average earning is between Rs. 100-200 per day. Today, Seelampur with a population of more than one million is a hub of manufacturing in Delhi, where thing like garments, toys, automobile parts, bags, shoes, needles, furniture and incense sticks are made in large numbers.

The mass-manufactured consumer goods are not produced in factories with giant machines, assembly lines and hundreds of workers as we might imagine. Rather, they are produced in hundreds of small-scale units, many of which are home-based and others which operate out of rented spaces with a small number of machines, mostly with family labour and with some hired workers. These units are categorized as 'informal' or 'unorganized' in official literature, because they are not registered with the government, do not have to pay taxes or report their activities to the government, and are outside the purview of most labour and industrial laws. Walk the streets here through dark passages, then down steps leading to the houses full of dismantled circuit boards strewn around along with the tons of electric wires piled up. Go closer and you see little girls and the mothers involved in stripping of wires of different thicknesses. They are ripping the plastic apart, hunting for precious metals. They usually work 10 hours a day in these dump dark enclosures which can hardly be called as a house. Rukhsana, 15, says, "Why should we go to school when we can make up to Rs. 200 every day this way". They segregate copper and aluminum from plastic of the wire with hand using a sharp edged weapon.

\section{Work As An Economic Exchange}

Here the barter system is very clear; someone called contractor will come to you, will ask you whether you are in need of work of wire stripping? If your answer is yes, he will explain the kind of wire he is going to supply you and when he will need it back. Prices are negotiable depending upon the kind of wire, the contractor's urgency as well as the laborer's willingness. Prices were decided as per kilogram and minimum buy was of $100 \mathrm{~kg}$. Almost whole family contributes to this labor intensive work. Generally, men get to strip thick wires like dish antenna cable, which needs more muscle power and a bigger tool to strip where as women were engaged in thin wire stripping. Thick wire gives aluminum and thin wire gives copper which is again weighted after stripping and if the weight is less than what the contractor has given to the family, the missing amount is deducted from their earning. From them we found out that the thin electric wire that is usually used in house, costs more as it is made of copper, but people won't prefer to put labor into it as it is difficult to strip them due to its thinness and chances of plastic wastage is more, which at the end will affect their earning.

\section{Stripping Of Wire: The Main Cause Behind Enviornmental Distress}

The wire stripping business involves buying electric wires of different thicknesses including panel feed wires (cable wires), PVC wires and single strand wires (commonly used in household). Stripping of wire is done with naked hands by using a sharp hook shaped blade. The blade is very sharp and the person doing wire stripping hurts himself countless times. But as they get good money from it hence won't mind getting these kind of cuts again and again. Extracting copper and PVC from discarded wires has become a household industry. Ustara (a very common tool used by barber to shave hair) is an instrument used to peel off the PVC coating from the cables and wires are cut and stripped for extraction of copper, in case when cables are of adequate length. Open burning is also a common scene in this area and is happened in case of when the wires and cables are of shorter lengths. A piece of cloth is wrapped around the wires and the cloth is being burnt, which lead to the melting of insulation and sheath. Non-metallic sheath used to protect the wire from flame, sunlight, abrasion, chemicals and moisture includes the use of natural and synthetic rubber sheaths, Polyvinyl Chloride popularly known as PVC sheath (most widely used because of its excellent physical property and low cost) and fabric sheaths. The recycling/dismantling units are located in the backyards or godowns or inside the houses as told by Salman (one of the worker in the Seelampur yard). This activity is done without any protection taken by the worker and this method releases lots of gases and chemicals which is harmful to the worker as well as to others in the surrounding. For instance, burning of PVC releases hydrogen chloride, which on inhalation mixes with water in the lungs to form hydrochloric acid. This can lead to corrosion of the lung tissues, and several respiratory complications.

Copper and aluminum has 90 and 80 percent recycling efficiency respectively and covers most of the stripping business, whereas silver and gold extraction is made mostly from dismantling of computers, circuit boards and other electronic wastes. The key electronic wastes comprises of an assortment of circuit boards, CRT tubes, copper, aluminum, iron, silver and gold flicks, PVC wires, plastic housing wires in large quantities, etc. Heavy metals which are originated from discarded e-products are found in landfills including hazardous metals like mercury and cadmium. The waste which does not have any re-use or resale value is openly burnt to 
minimize the e-waste volume. Aluminum is produced in larger quantity as compared to other metals as it is present in large content in computers and the PVC cables. Its recycling efficiency is 10 percent lower than copper but still generated and recycled in larger volume than other metals present in e-products. Extraction of aluminum from the plastic wires follows an extraneous procedure. First of all the pile of wire is heated on a constant flame to make the plastic coating softer. Then, the person who is stripping the wire has to sit in a particular posture which involves spreading of one leg in a particular way and frequently leaning forward and backward consecutively. It puts immense pressure on vertebral column as well as the spinal cord and related illness is very common among the population.

\section{Conclusion}

The name of India's capital inevitably conjures up images of authority, power and prosperity. Symbols like Red Fort, Qutab Minar and the Walled City that have existed for centuries, the colonial constructions of India Gate, Connaught Place, well-manicured landscapes of Lutyens' Delhi, and the iconic Delhi Metro, malls, offices and luxury apartments and the Commonwealth Games Village of 21st century, all come to mind whenever we talk about or imagine the city. Yet, Delhi is also one of the most densely populated cities of the subcontinent, a state with 15 million people, most of whom have arrived here as migrants in search of shelter, work and economic opportunities and kept on flowing with course of time. The lives of these people are intertwined and at the same time, separated from the glamour and glitz of the metropolis. They do myriad kinds of work to earn a living, from manufacturing food products, plastic, wood, paper, electronic and metal products to working in offices, driving rickshaws, transporting goods, and selling consumer products in shops, markets and streets. Shops and godowns, workshops, residential buildings and slum tenements, mosques and markets, jostle each other for space in the area. People involved in odd kind of jobs like stripping of wires, live close to where they work, or they work in the same space where they live. The informal business of e-waste has become a means of livelihood for unorganized recycling traders and workers. But, due to lack of awareness of the hazards involved in recycling activities, these workers unfortunately put their health to risk and at the same time they also endanger the environment through polluting by these activities. The paradigm of socio-economic status of the community living in the Seelampur locality of east Delhi is an interesting area of study and it has the potential to cater vast range of research fields in sociological, economical, cultural and political studies.

\section{Acknowledgment}

I would like to thank my supervisor Prof. Subhadra Channa for her guidance and valuable suggestions. I would also like to thank my respondents in the Seelampur area for having patient during my long sessions of interviews. Last but not the least; I am deeply indebted to my funding agency, Indian Council of Medical Research, Ansari Nagar, New Delhi for financial assistance.

\section{References}

[1]. Vertovec, Steven. (ed.) (2010), Anthropology of Migration and Multiculturalism: New Directions, Routledge Publication, London and New York

[2]. World Migration Report 2010 - The Future of Migration: Building Capacities for Change, International Organization for Migration.

[3]. Rajan, S. Irudaya (ed.), (2010), 'Governance and Labour Migration', India Migration Report 2010, Routledge Publication, New Delhi.

[4]. Bauder, Harald. (1st edition) (2006), Labour Movement: How Migration Regulates in Labor Markets, Oxford University Press, London.

[5]. Abdelmalek, Sayad. (2004), The Suffering by the Immigrants, Preface by Pierre Bourdieu, Polity Press: UK.

[6]. Kundu Nandita Kapadia, Tara Kanitkar, (2002), "Primary Healthcare in Urban Slums", Economic and Political Weekly, Dec 21, pp. 5086-5089.

[7]. Helman, Cecil G. (2000), Culture, Health and Illness, Reed Educational Publishing, Oxford: London.

[8]. Ravenstein, E. G. (1885), "The Laws of Migration", Journal of the Statistical Society, vol. 46, pp. 167-235. 